\title{
Leukotriene-A4-Hydrolase and Basic Aminopeptidase Activities Are Related with Collagen-Induced Arthritis in a Compartment-Dependent Manner
}

\author{
Mariana Trivilin Mendes ${ }^{1,2}$, Paulo Flavio Silveira ${ }^{1}$ \\ ${ }^{1}$ Laboratory of Pharmacology, Unit of Translational Endocrine Physiology and Pharmacology, Instituto Butantan, São Paulo, Brazil; \\ ${ }^{2}$ Department of Physiology, Instituto de Biociências, Universidade de São Paulo, São Paulo, Brazil. \\ Email: paulo.silveira@butantan.gov.br
}

Received September $23^{\text {rd }}, 2013$; revised October $23^{\text {rd }}, 2013$; accepted October $30^{\text {th }}, 2013$

Copyright (C) 2013 Mariana Trivilin Mendes, Paulo Flavio Silveira. This is an open access article distributed under the Creative Commons Attribution License, which permits unrestricted use, distribution, and reproduction in any medium, provided the original work is properly cited.

\begin{abstract}
Objective: Previous study demonstrated the involvement of basic aminopeptidase (APB) activity in the development of collagen-induced arthritis (CIA). Two zinc dependent metalloenzymes (EC 3.4.11.6 and EC 3.3.2.6) are known to exhibit concomitantly APB and leukotriene-A4-hydrolase (LT-A4-H) activities. Influence of the interrelationship between both activities on arthritic processes, however, is presently uncertain. This study aimed to compare these activities in CIA. Methods: CIA was induced in rats and arthritis was assessed macroscopically. Ultracentrifugation was used to separate soluble (S) and solubilized membrane-bound (M) fractions from peripheral blood mononuclear cells (PBMCs) and synovial tissue (ST). Enzyme immunoassay was used to measure LT-A4-H activity, and Real Time Polymerase Chain Reaction was used for evaluating EC 3.4.11.6 and EC 3.3.2.6 gene expressions. Results: The existence of genes for EC 3.3.2.6 and EC 3.4.11.6 was demonstrated in the ST. Compared with control, LT-A4-H activity increased in synovial fluid (SF) and in S-PBMCs of CIA-arthritic and CIA-resistant and in M-ST of CIA-resistant, while it decreased in M-PBMCs of CIA-arthritic and CIA-resistant. In all these locations APB activity remained unchanged or inversely correlated with LT-A4-H activity. Conclusions: LT-A4-H and APB activities in joint-related samples are associated, for the first time, with EC 3.3.2.6 and EC 3.4.11.6 genes, exhibiting a compartment-dependent differential modulation of their specificity, efficiency and/or affinity or an inverse concurrent pattern. Changes in LT-A4-H activity have implications for development or resistance to arthritis in CIA model with a potential to be a diagnostic tool.
\end{abstract}

Keywords: Aminopeptidase; Ether Hydrolase; Bifunctional Enzyme; Eicosanoids

\section{Introduction}

Rheumatoid arthritis (RA) is characterized by peripheral polyarthritis with cartilage and bone erosions, resulting in deformity and joint destruction [1]. This process is associated with inflammatory hyperplasia of the synovial membrane, also known as pannus [2]. What happens is the neovascularization, which occurs after the infiltration of inflammatory cells into the synovial membrane [3] and the immune response against cartilage components, among them the type II collagen (CII) has been most commonly associated with this response [1]. The arthritis induced by CII (CIA) [4-9] generates an erosive polyarthritis $[5,8,10]$ that has been intensively studied due to its similarities with the RA [4,6,9-11], mainly regarding the development of synovitis, progressive pannus formation, marginal erosion of bone and cartilage destruction $[4,6,8]$. In CIA model the symptoms in rats and mice begin about 21 days after the CII injection at currently used dose [9].

The role of enzymes in the etiology of inflammatory diseases, such as RA and osteoarthritis, has been the focus of many investigations [12-14]. Two zinc dependent metalloenzymes [15-18], leukotriene (LT)-A4 hydrolase (LT-A4-H) (EC 3.3.2.6) and basic aminopeptidase (APB) (EC 3.4.11.6), seem to exhibit concomitant hydrolytic activities on L-arginyl- $\beta$-naphthylamide (ArgNA) and on LT-A4 [18-23].

EC 3.4.11.6 preferentially hydrolyzes basic residues (Arg and Lys) of peptides [17,18,24,25], being ArgNA 
its preferential synthetic substrate [26]. This enzyme is structurally similar to EC 3.3.2.6 (33\% identity and 48\% similarity) and it has also been reported to exhibit LTA4-H activity $[16,17,27]$. Whether there is a reciprocal interference of peptide and eicosanoid substrates in each one of these possible catalytic activities of EC 3.4.11.6 is not known. Mantle et al. [22] suggest that changes in LTs generate changes in the APB activity. Although the EC 3.4.11.6 gene expression has not yet been evaluated in joint-related samples, the APB activity [28] and other aminopeptidase activities, such as neutral and dipeptidyl peptidase IV [29], have already been implicated in the etiology and development of arthritis in CIA model. The potential importance of APB activity in RA could be related to their participation in the peptides processing [30]. One hypothesis is its association with the post-translational maturation in the trans-Golgi network, and with the regulatory processes in the plasma membrane, which includes extracellular hydrolysis of several peptide substrates. Moreover, APB can participate in the final stages of processing of hormones precursors [15]. The significance and even the existence of the two catalytic functions of EC 3.4.11.6 remain unknown [15,17,25], but its hydrolytic ability in a wide $\mathrm{pH}$ range is suggestive of its adaptability to various cellular sub-compartments, which has been reinforced by some reports about its involvement in a broad spectrum of pathophysiological processes $[15,17]$, including the RA [28].

EC 3.3.2.6 from human and rodent is a soluble and monomeric enzyme [18,31], with at least one report also showing a membrane-bound LT-A4-H activity in hepatocytes [32]. In addition to the epoxide hydrolase activity upon LT-A4, the EC 3.3.2.6 also seems to exhibit activity upon ArgNA [19]. Both catalytic activities of EC 3.3.2.6 were reported to be inhibited by divalent cations, while only aminopeptidase activity was stimulated by monovalent anions such as chloride [18,21]. Although the involvement of EC 3.3.2.6 in RA by means of the LT-B4 (acid 5[S], 12[R]-dihydroxy-6,14-cis-8,10-transeicosatetraenoic) formation is an attractive and predictable hypothesis, studies in this direction are rare [33]. In addition, EC 3.3.2.6 gene expression has also not yet been evaluated in joint-related samples. The LT-B4 is a potent pro-inflammatory mediator synthesized by immune cells, such as eosinophils, neutrophils and macrophages, which stimulates the production of several cytokines [16] and it has been recognized as a potent chemotactic factor during early inflammation [34,35]. Moreover, it promotes degranulation, increased release of lysosomal enzymes and superoxide production by neutrophils [36,37].

To know the possible changes in LT-A4-H activity in CIA model, as well as to infer its involvement in the pa- thophysiology and its potential to be a RA biomarker are important tasks. In addition, the knowledge of the gene expression of EC 3.3.2.6 and EC 3.4.11.6 and the comparative analysis of the catalytic activities upon LT-A4 and ArgNA in CIA model may contribute to the identification of interrelation pattern of these catalytic functions in both proteins. For this purposes this study evaluates the gene expression of EC 3.3.2.6 and EC 3.4.11.6, as well as the levels of LT-A4-H activity (LT-A4 hydrolysis) in comparison with APB activity levels (ArgNA hydrolysis) reported by Mendes et al. [28].

\section{Materials and Methods}

\subsection{Animals and Treatments}

Adult male Wistar rats, weighing 160 - $180 \mathrm{~g}$ and maintained in polyethylene cages with food and tap water $a d$ libitum in a container with controlled temperature of $25^{\circ} \mathrm{C}$, relative humidity of $65.3 \% \pm 0.9 \%$ and $12 \mathrm{~h}: 12 \mathrm{~h}$ photoperiod light:dark (lights on at 6:00 am), were sub jected to the following procedures approved by the Ethics Committee on Animal Use of Butantan Institute (682/09). Based on Cremer method (1998), modified by Mendes et al. [28], the animals were injected with CII from chicken (Sigma, USA) dissolved in $0.01 \mathrm{M}$ acetic acid and emulsified in equal volume of Freund's incomplete adjuvant (Sigma) (prepared at $4{ }^{\circ} \mathrm{C}$ just before use), via single intradermal dose of $0.4 \mathrm{mg} / 0.2 \mathrm{~mL} / \mathrm{animal}$, into the proximal one-third of the tail (induced animals), or with $0.9 \%$ saline at the same scheme of administration (sham induction). All animals that received the emulsion or saline were previously anesthetized with a solution of ketamine (3.75\%) (Fort Dodge, USA) and xylazine $(0.5 \%)$ (Vetbrands, Brasil) at a dose of $0.2 \mathrm{~mL} / 100 \mathrm{~g}$ body weight, via intraperitoneal (ip). All these procedures mentioned above, as well as the evaluation of edema, erythema and cyanosis, and the collection of samples were carried out in the morning.

\subsection{Macroscopic Assessment of Arthritis}

Erythema and cyanosis were observed, and dorsal-plantar thickness of the hind paws in the region of the metatarsus was quantified with paquimeter (Mitutoyo, USA). Both paws were measured and mean thickness for each animal was calculated. This measurement was performed immediately before the euthanasia and sample collection.

\subsection{Sample Collection}

On $41^{\text {st }}$ day after treatments, the animals were anesthetized using the same scheme specified above and thus the following experimental groups were formed: Control (all animals submitted to sham induction); Arthritic (induced 
animals with hind paw thickness $>5.7 \mathrm{~mm}$ that also present erythema and cyanosis); Resistant (induced animals without erythema and cyanosis and with hind paw thickness similar to control). Thus, blood was withdrawal from the left ventricle with heparinized syringes and used to obtain peripheral blood mononuclear cells (PBMCs) or centrifuged (at $200 \times \mathrm{g}$ for $10 \mathrm{~min}$ at at $4^{\circ} \mathrm{C}$ ) to obtain plasma. The SF and ST were subsequently removed from both knees of each animal as follows: $200 \mu \mathrm{L}$ of $0.9 \%$ $\mathrm{NaCl}$ was injected intraarticularly into each knee with an ultrafine needle $(0.45 \times 13 \mathrm{~mm})$ and aspirated with a syringe and, after such washing, the ST was excised together with the connective tissue of the joint capsule.

\subsection{Gene Expressions of EC 3.4.11.6 and EC 3.3.2.6}

\subsubsection{RNA Extraction}

The RNA of ST suspension for each control healthy animal was extracted using the sound RiboPure ${ }^{\mathrm{TM}} \mathrm{Kit}$ (Applied Biosystems, USA) as recommended by the manufacturer. Briefly, the ST samples were homogenized on ice with TriReagent ${ }^{\circledR}$ (Applied Biosystems) $(1 \mathrm{~mL}$ TriReagent ${ }^{\circledR}$ for each 0.05 to $0.1 \mathrm{mg}$ of original tissue) on Polytron ${ }^{\circledR} 11,000 \mathrm{rpm}$ and sequentially incubated for $5 \mathrm{~min}$ at $25^{\circ} \mathrm{C}$ and centrifuged at $12,000 \times \mathrm{g}$ for $10 \mathrm{~min}$ at $4^{\circ} \mathrm{C}$. Afterward, $200 \mu \mathrm{L}$ chloroform were added to each $1 \mathrm{~mL}$ of sample and mixed by a vortex at a maximum speed for $15 \mathrm{sec}$ and then incubated for $5 \mathrm{~min}$ at $25^{\circ} \mathrm{C}$ and centrifuged at $12,000 \times \mathrm{g}$ for $10 \mathrm{~min}$ at $4^{\circ} \mathrm{C}$. Three layers were formed after this centrifugation: a top, or aqueous phase, composed of RNA; an intermediate phase, composed of DNA; and a lower, or phenol phase, composed of protein. $400 \mu \mathrm{L}$ of aqueous phase were transferred to a new tube, and thus mixed with $200 \mu \mathrm{L}$ ethanol (99.5\%) and homogenized by a vortex mixer for $15 \mathrm{sec}$ and transferred to a Filter Cartridge-Collection Tube. Subsequently, this apparatus was centrifuged at $12,000 \times \mathrm{g}$ for 30 sec at $25^{\circ} \mathrm{C}$ and the liquid drained into the collector tube was discarded, while the filter containing the RNA was placed in the same collector tube and washed with 500 $\mu \mathrm{L}$ of wash solution. This washing was repeated twice more. Subsequently, the filter was centrifuged at 12,000 $\times \mathrm{g}$ for $30 \mathrm{sec}$ at $25^{\circ} \mathrm{C}$ to remove residual wash solution and then the filter was transferred to a new collector tube where $100 \mu \mathrm{L}$ of elution buffer were added. After incubation for 2 min at $25^{\circ} \mathrm{C}$, this Filter Cartridge coupled with this new Collection Tube were centrifuged at 12,000 $\times \mathrm{g}$ for $30 \mathrm{sec}$ at $25^{\circ} \mathrm{C}$ and the final eluate containing the RNA was obtained and stored at $-20^{\circ} \mathrm{C}$ until used.

\subsubsection{Quantitative Real Time Polymerase Chain Reaction (qPCR)}

The total RNA isolated was quantified and its purity was evaluated by Synergy ${ }^{\mathrm{TM}} \mathrm{H} 1$ using the software Gen5 ${ }^{\mathrm{TM}}$. The adequate quality of total RNA was checked by the existence of bands corresponding to $25 \mathrm{~S}$ and $18 \mathrm{~S}$ ribosomal RNA, obtained in 1\% agarose (Amersham Bioscience, Sao Paulo, SP, Brazil) gel electrophoresis (wt/v), prepared in Tris/sodium acetate/EDTA 1x buffer, $\mathrm{pH}$ 8.0, under constant voltage $(80 \mathrm{~V})$, and stained with ethidium bromide solution $(0.5 \mu \mathrm{g} / \mathrm{mL})$ under ultraviolet light. As recommended by manufacturer, until $2 \mu \mathrm{g}$ of total RNA in a maximum volume of $9 \mu \mathrm{L}$ were used for reverse transcription procedure using the High Capacity RNA-tocDNA kit (Applied Biosystems). Briefly, $10 \mu \mathrm{L}$ of reaction buffer, $1 \mu \mathrm{L}$ of enzyme mix and the sample at final volume of $20 \mu \mathrm{L}$ in $0.01 \%$ diethylpyrocarbonate (DEPC) (Sigma) in sterile deionized water were placed in the thermal cycler for $60 \mathrm{~min}$ at $37^{\circ} \mathrm{C}$ and for $5 \mathrm{~min}$ at $95^{\circ} \mathrm{C}$. Them, the samples were stored at $-80^{\circ} \mathrm{C}$. The expression of APB and LT-A4-H mRNAs was measured with Taqman system ${ }^{\circledR}$. In addition to the primers, a probe that selectively hybridizes with cDNA was used. The thermal cycler conditions for the PCR reaction were: 1 cycle of 2 min at $50^{\circ} \mathrm{C}, 1$ cycle of $10 \mathrm{~min}$ at $95^{\circ} \mathrm{C}$, followed by 40 cycles: $15 \mathrm{sec}$ at $95^{\circ} \mathrm{C}$ and $1 \mathrm{~min}$ at $60^{\circ} \mathrm{C}$. APB (Rn 00579477 m1, GenBank: NM 020216) and LT-A4-H (Rn01503878_m1, acess number to GenBank: NM_001030031) primers and probes and GAPDH (GenBank: NM_017008) (positive control) used were purchased from Life Technologies (Brazil). Relative gene expression was determined using the $\Delta \Delta \mathrm{C}_{\mathrm{T}}$ method $\left(\Delta \mathrm{C}_{\mathrm{T}(\text { sample) }}-\Delta \mathrm{C}_{\mathrm{T}(\text { reference)})}\right.$, threshold cycle). The comparative $\mathrm{C}_{\mathrm{T}}$ method is a mathematical model that consists of normalizing the number of target gene copies to an endogenous reference gene (GAPDH) and compare it to control sample (that with highest cycle threshold and, consequently, lowest gene expression) designed as the calibrator.

\subsection{Obtaining PBMCs}

According to the method of Grage-Griebenow et al. [38], heparinized blood was carefully layered on Percoll (density $=1.077 \mathrm{~g} / \mathrm{mL})(\mathrm{GE}-$ Healthcare, USA $)$ in PBS $(56 \%)$ at a proportion of $5: 3(\mathrm{v} / \mathrm{v})$ and subsequently centrifuged $\left(1000 \times \mathrm{g}\right.$ for $40 \mathrm{~min}$ at $\left.25^{\circ} \mathrm{C}\right)$. The layer containing the PBMCs was then removed from the tube and transferred to microtubes to be immediately used.

\subsection{PBMCs Counting and Viability}

$20-\mu \mathrm{L}$ aliquots of PBMCs suspension were diluted with Turk's fluid $(1: 20, \mathrm{v} / \mathrm{v})$. The cell viability was assessed using $40 \mu \mathrm{L}$ aliquots of this suspension diluted in equal volume of Trypan. Cell counting was performed in a Neubauer chamber under optical microscopy. 


\subsection{Fractionation of ST and PBMCs}

As previously described by Mendes et al. [28], the ST from both knees of each animal was homogenized in 10 $\mathrm{mM}$ Tris- $\mathrm{HCl}$ buffer, $\mathrm{pH} 7.4(0.1 \mathrm{~g}$ tissue $/ 3.0 \mathrm{~mL})$ for 3 $\mathrm{min}$ at 15,000 rpm (homogenizer Polytron-Aggregate, Kinematica, Switzerland). PBMCs homogenates were sonicated in $10 \mathrm{mM}$ Tris- $\mathrm{HCl}, \mathrm{pH} 7.4\left(3.0 \times 10^{6}\right.$ cells $\left./ \mathrm{mL}\right)$, for $10 \mathrm{sec}$ at amplitude level of $40 \mu \mathrm{m}$ at a constant frequency of $20 \mathrm{kHz}$. These samples were then ultracentrifuged at $100,000 \times \mathrm{g}$ for $35 \mathrm{~min}$ (ultracentrifuge Hitachi CP60E). The resulting supernatants correspond to soluble (S) fraction. The resulting pellets were washed twice with the same buffer and ultracentrifuged at $100,000 \times \mathrm{g}$ for $35 \mathrm{~min}$, to assure the complet removal of $\mathrm{S}$. The pellet was homogenized for $3 \mathrm{~min}$ at $800 \mathrm{rpm}$ (homogenizer Tecnal TE 099) with the same volume of the same buffer plus Triton X-100 (Sigma) (0.1\%) and ultracentrifuged again $(100,000 \times \mathrm{g}$ for $35 \mathrm{~min})$. The resulting supernatants correspond to solubilized membrane-bound (M) fraction. All procedures were carried out at $4{ }^{\circ} \mathrm{C}$. The efficiency of this fractionation in both materials was previously demonstrated using lactate dehydrogenase activity as a marker [28,29].

\subsection{LT-A4-H Activity}

\subsubsection{Incubation of Samples with or without LT-A4} Based on the methodology of Mendes et al. [20], $1 \mu \mathrm{L}$ of LT-A4 solution (Sigma) (100 $\mu \mathrm{g} / \mathrm{mL})$ was diluted in $1499 \mu \mathrm{L}$ of $50 \mathrm{mM}$ HEPES buffer (Sigma), pH 7.5, containing $0.0625 \%$ glycerol (USB Co., USA) and 1\% dimethyl sulfoxide (DMSO) (Sigma). Alternatively, $1 \mu \mathrm{L}$ of LT-A4 solution was substituted by $1 \mu \mathrm{L} 0.9 \% \mathrm{NaCl}$ in this mixture. $50 \mu \mathrm{L}$ of plasma, SF, and $\mathrm{S}$ and $\mathrm{M}$ from ST and PBMCs and $250 \mu \mathrm{L}$ of buffer solution mentioned above containing or not LT-A4 (LT-A4 final concentration $=166.66 \mathrm{nM})$ were pipetted into each microplate well (96 wells) (Corning) and then incubated $\left(25^{\circ} \mathrm{C}\right)$ under orbital shaking $(250 \mathrm{rpm})$ for $10 \mathrm{~min}$. Thus, $10 \mu \mathrm{L}$ of each incubated were transferred to a microtube containing $190 \mu \mathrm{L}$ of ice-cold assay buffer (EIA buffer) from EIA kit for LT-B4 (Leukotriene B4 EIA kit using monoclonal antibody produced in mice against LT-B4 rabbit, Cayman Chemical, USA).

\subsubsection{Enzyme Immunoassay (EIA)}

The absorbance at $\lambda=412 \mathrm{~nm}$ of each samples obtained as described above was read against two HEPES buffer solutions, with or without LT-A4, both considered the "blank" of each kind of incubation, and also against the "blank" supplied with the kit.

\subsubsection{Catalytic Activity}

The values of the blanks were subtracted and the relative absorbance was converted to pg of LT-B4 formed in 1 min of incubation per $1 \mathrm{~mL}$ of sample by an interpolation in a correspondent standard curve. The values of LT-B4 formed in each samples incubated without LT-A4 (endogenous LT-B4) were subtracted from the values of LTB4 in the same samples incubated with LT-A4 thus representing the value of LT-B4 formed in vitro. The LTA4-H activity was expressed as pg of LT-B4 formed in vitro/min $/ \mathrm{mL}$ sample.

\subsection{Data Analysis}

Data are shown as mean \pm standard error of the mean (S.E.M) and were analyzed statistically using the GraphPad Instat ${ }^{\mathrm{TM}}$ software package. Regression analysis was performed to obtain standard curve of LT-B4. To compare values among the control, arthritic and resistant groups one-way analysis of variance (ANOVA) was performed, followed by Student-Newman-Keuls multiple comparisons test when differences were detected. In all the calculations a minimum critical level of $\mathrm{P}<0.05$ was set.

\section{Results}

\subsection{Classification of Experimental Animals Based on the Formation of Edema, Erythema and Cyanosis}

The swelling (in mm; $\mathrm{n}=$ number of animals, two-tailed unpaired Student's t-test $p<0.0017$ ), erythema and cyanosis were the main macroscopic characteristics of the hind paws of arthritic animals. Severe swelling (5.899 \pm $0.037, \mathrm{n}=10$ ) was found in $60 \%$ of animals treated with CII. Compared to controls $(4.745 \pm 0.052, \mathrm{n}=10), 30 \%$ of the animals treated with CII showed no erythema, cyanosis or edema $(4.762 \pm 0.309, \mathrm{n}=10)$. These data agree with the differential detection of serum TNF- $\alpha$ levels and histopathological alterations of the tibio-tarsal joint in the CII treated animals that develop severe edema (CIA-arthritic), which can be thus confidentially distinguished from CIA-resistant (without edema) [28,29]. Based on the macroscopic classification of edema formation, preconized by Erlandsson Harris et al. [39], all arthritic animals selected here had the maximum score in hind paws. $10 \%$ of CII treated animals were discarded because they did not reach this level of arthritis.

\subsection{Gene Expression of APB (EC 3.4.11.6) and LT-A4-H (EC 3.3.2.6)}

Figure 1 shows that APB (EC 3.4.11.6) and LT-A4-H (EC 3.3.2.6) genes are expressed in ST of healthy control animals.

\subsection{LT-A4-H Activity}

Table 1 shows LT-A4-H activity in plasma, SF, and S 
and $\mathrm{M}$ from ST and PBMCs. Compared to controls, this activity is higher in SF and in S from PBMCs and lower in $\mathrm{M}$ from PBMCs in CIA-arthritic and CIA-resistant, and higher in $\mathrm{M}$ from ST in CIA-resistant.

Table 2 illustrates altered LT-A4-H (present study) and APB [28] activities in CIA-arthritic and CIA-resistant compared to healthy control rats.

\section{Discussion}

The existence of the genes for EC 3.3.2.6 and EC 3.4.11.6 was confirmed in the synovial tissue of healthy controls rats. The synovial tissue and synovial fluid collected from animals under study contain infiltrating leukocytes. Therefore, the total content of both activities in plasma, synovial fluid and synovial tissue should be at least partially derived from these cells, particularly in arthritic animals.

The present work showed parallel changes in LT-A4-H

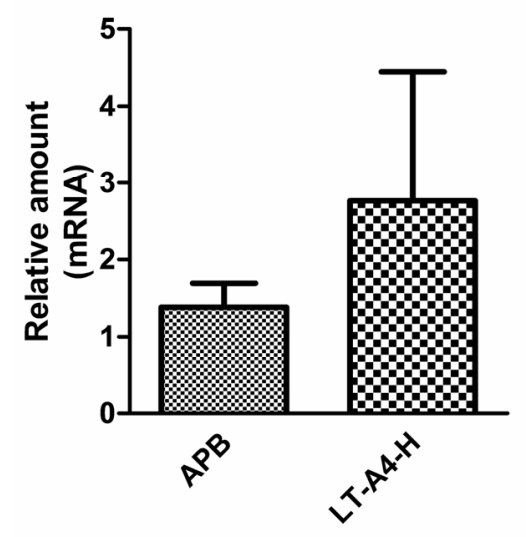

Figure 1. Relative gene expression of basic aminopeptidase (APB) (EC 3.4.11.6) and LT-A4 hydrolase (LT-A4-H) (EC 3.3.2.6) in synovial tissue of healthy control animals. Number of animals $=2$.

Table 1. LT-A4-H activity ${ }^{*}$.

\begin{tabular}{|c|c|c|c|c|}
\hline Samples & Control & CIA-Arthritic & CIA-Resistant & $A N O V A(\mathrm{p})$ \\
\hline PLASMA & $7.03 \pm 0.26$ & $9.73 \pm 1.12$ & $9.84 \pm 1.27$ & $=0.1540$ \\
\hline SF & $4.26 \pm 0.29^{\mathrm{a}}$ & $7.12 \pm 0.45^{\mathrm{b}}$ & $15.11 \pm 1.01^{\mathrm{c}}$ & $<0.0001$ \\
\hline S-ST & $19.42 \pm 2.76$ & $13.06 \pm 2.30$ & $17.64 \pm 1.55$ & $=0.2023$ \\
\hline M-ST & $4.66 \pm 0.01^{\mathrm{a}}$ & $0 \pm 1.16^{\mathrm{a}}$ & $18.94 \pm 5.08^{b}$ & $=0.0060$ \\
\hline S-PBMCs & $0 \pm 4.20^{\mathrm{a}}$ & $7.32 \pm 3.37^{\mathrm{b}}$ & $253.60 \pm 1.76^{\mathrm{c}}$ & $<0.0001$ \\
\hline M-PBMCs & $47.88 \pm 10.66^{\mathrm{a}}$ & $19.32 \pm 4.89^{b}$ & $16.44 \pm 0.21^{\mathrm{b}}$ & $=0.0306$ \\
\hline
\end{tabular}

*pg LT-B4 formed/min/mL of plasma, synovial fluid (SF) or soluble (S) and solubilized membrane-bound (M) fractions from synovial tissue (ST) and peripheral blood mononuclear cells (PBMCs) of control, arthritic and resistant rats. Values are means of duplicates \pm SEM. Number of animals $=3$. Comparison of the same samples among groups. Post hoc Student-Newman-Keuls (different letters indicate statistical differences: $p<0.05$ ).
Table 2. Changes in LT-A4-H and APB activities in CIAarthritic and CIA-resistant relatively to healthy control rats.

\begin{tabular}{ccccc}
\hline \multirow{2}{*}{ Samples } & \multicolumn{2}{c}{ LT-A4-H activity } & \multicolumn{2}{c}{ APB activity } \\
\cline { 2 - 5 } & CIA-Arthritic & CIA-Resistant & CIA-Arthritic CIA-Resistant \\
\hline PLASMA & $=$ & $=$ & $=$ & $\downarrow$ \\
SF & $\uparrow$ & $\uparrow$ & $=$ & $\downarrow$ \\
S-ST & $=$ & $\uparrow$ & $\uparrow$ & $=$ \\
M-ST & $=$ & $\uparrow$ & $\downarrow$ & $\downarrow$ \\
S-PBMCs & $\uparrow$ & $\downarrow$ & $=$ & $\uparrow$ \\
M-PBMCs & $\downarrow$ & $\downarrow$ & $\uparrow$ &
\end{tabular}

LT-A4-H activity assessed by EIA and APB activity assessed by fluorometry $[28] .(=)$ No difference, $(\downarrow)$ decrease, $(\uparrow)$ increase.

activity in arthritic and resistant rats in relation to controls, although quantitative levels of these changes are distinct in some materials. Thus, regarding the LT-A4-H activity both, arthritic and resistant, are distinguishable from the controls, on the other hand they are distinct from each other only quantitatively. These features can be useful in further studies exploring the LT-A4-H activity as a diagnostic tool and the role of quantitative differences of this activity in the development and resistance to arthritis. The structural analysis of EC 3.3.2.6 and EC 3.4.11.6 showed that the differences in their distributions of electrostatic potential may reflect different interactions between protein-protein and/or the protein and the environment in which it is inserted, with EC 3.3.2.6 having less hydrophobic parts than EC 3.4.11.6 [15]. Different negative electrostatic potential in the catalytic site could explain the different specificities for their respective substrates [15], implying on the possibility that different catalytic activities do not interfere with each other. Another report shows that EC 3.4.11.6 from rat and human has no epoxy-hydrolase activity, suggesting that despite the great structural similarity between EC 3.3.2.6 and EC 3.4.11.6, the last one has another function [40]. The present study shows that changes in LT-A4-H and APB activities do not coincide in the plasma and membrane-bound fraction from the synovial tissue of resistant animals, as well as in soluble and membranebound fractions from synovial tissue, membrane-bound fraction from PBMCs and synovial fluid of arthritic animals. These results suggest the existence of differential modulation of catalytic specificity, efficiency and/or affinity of EC 3.3.2.6 and EC 3.4.11.6 enzymes on peptide and epoxy substrates, or that they act independently with a single catalytic action in these locations. However, in those situations where APB and LT-A4-H activities change concomitantly, such changes are inversely correlated, cor- 


\section{ARTHRITIC}

\section{RESISTANT}

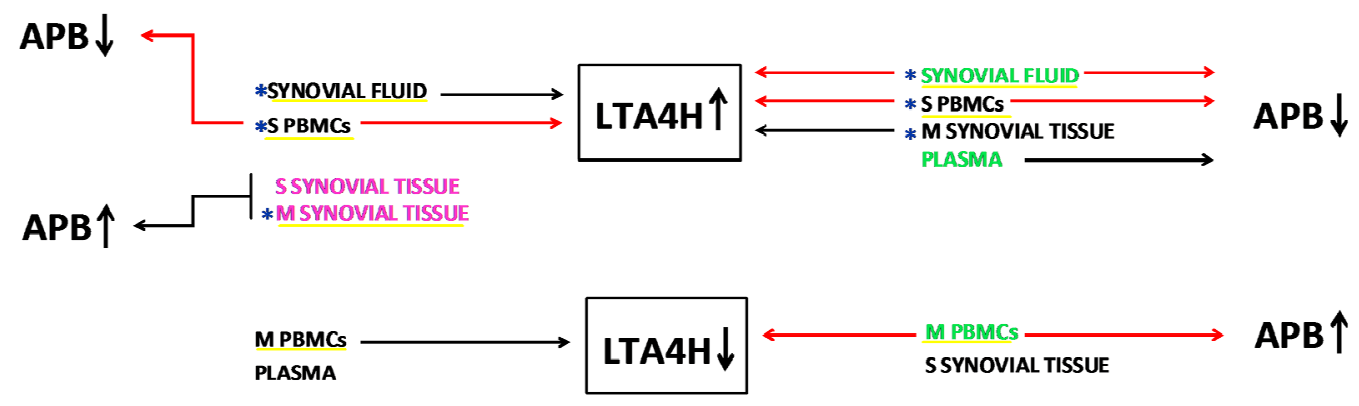

Figure 2. Schematic depicting the changes in LT-A4-H and APB activities in CIA-arthritic and CIA-resistant rats. Arrows $\uparrow$ and $\downarrow$ indicate, respectively, increased or decreased values relatively to healthy control rats. Locations where activity levels of APB are markers of arthritis or resistance [28] are respectively written in pink and green. The changes in the way and levels of LT-A4-H activity in any of examined locations underlined in yellow, except in plasma and S-ST of arthritic and resistant and in M-ST of arthritic, distinguish arthritic and/or resistant from controls and thus they have potential diagnostic use. The changes in the way of LT-A4-H activity in any of the examined locations, except in M-ST, do not distinguish between arthritic and resistant (see Table 2), but the changes in the levels of LT-A4-H activity in locations marked with blue asterisk (SF, M-ST and S-PBMCs) (see Table 1) may have implications for the resistance or development of arthritis in CIA model. The red solid lines indicate all the situations and locations where occur concomitant changes in activity levels of LT-A4-H and APB, showing that they are always inversely correlated.

roborating the existence of a bifunctional pattern currently described for EC 3.4.11.6 [15,25,27] and EC 3.3.2.6 $[17,35,41]$.

Taken together, the results of the present study subsidize the scheme proposed in Figure 2, illustrating a hypothetical mechanism of interrelation between LT-A4-H and APB activities in CIA-arthritic and CIA-resistant in comparison with healthy control rats.

\section{Conclusion}

In summary, LT-A4-H (EC 3.3.2.6) and APB (EC 3.4.11.6) gene expressions were shown for the first time in joint-related samples from rats. Another interesting result is the fact that LT-A4-H and APB activities behave in a compartment-dependent manner. Moreover, these activities exhibit differential modulation of their specificity, efficiency and/or affinity or an inverse concurrent pattern. In this way, as previously observed for APB [28], changes in LT-A4-H activity also have implications in the development or resistance to arthritis in CIA model and deserve further investigation as a possible diagnostic tool.

\section{Acknowledgements}

This study was financially supported by a Research Grant 09/17613-0 from FAPESP (Fundação de Amparo à Pesquisa do Estado de São Paulo, Brazil). P.F.S was recipient of a Productivity Grant 302533/2011-7 from CNPq (Conselho Nacional de Desenvolvimento Cientifico e Te- cnologico, Brazil). M.T.M. was recipient of a CAPES (Coordenacao de Aperfeicoamento de Pessoal de Nivel Superior, Brasil) fellowship. The authors thank all the staff at the Unit of Translational Endocrine Pharmacology and Physiology at Laboratory of Pharmacology for technical support.

\section{REFERENCES}

[1] R. Holmdahl, J. C. Lorentzen, S. Lu, P. Olofsson, L. Wester, J. Holmberg and U. Pettersson, "Arthritis Induced in Rats with Nonimmunogenic Adjuvants as Models for Rheumatoid Arthritis," Immunological Reviews, Vol. 184, No. 1, 2001, pp. 184-202. http://dx.doi.org/10.1034/j.1600-065x.2001.1840117.x

[2] J. M. Stuart, A. S. Townes and A. H. Kang, "Collagen Autoimmune Arthritis," Annual Reviews in Immunology, Vol. 2, 1984, pp. 199-218.

http://dx.doi.org/10.1146/annurev.iy.02.040184.001215

[3] G. S. Panayi, "B Cells: A Fundamental Role in the Pathogenesis of Rheumatoid Arthritis?" Rheumatology, Vol. 44, No. S2, 2005, pp. ii3-ii7.

http://dx.doi.org/10.1093/rheumatology/keh616

[4] H. Kim, J. Bang, H. W. Chang, J. Y. Kim, K. U. Park, S. H. Kim, K. J. Lee, C. H. Cho, I. Hwang, S. D. Park, E. Ha and S. W. Jung, "Anti-Inflammatory Effect of Quetiapine on Collagen-Induced Arthritis of Mouse," European Journal of Pharmacology, Vol. 678, No. 1-3, 2012, pp. 55-60. http://dx.doi.org/10.1016/j.ejphar.2011.12.017

[5] D. D. Brand, A. H. Kang and E. F. Rosloniec, "Immunopathogenesis of Collagen Arthritis," Springer Seminars in Immunopathology, Vol. 25, No. 1, 2003, pp. 3-18. 
http://dx.doi.org/10.1007/s00281-003-0127-1

[6] L. K. Myers, E. F. Rosloniec, M. A. Cremer and A. H. Kang, "Collagen-Induced Arthritis, an Animal Model of Autoimmunity," Life Sciences, Vol. 61, No. 19, 1997, pp. 1861-1878.

http://dx.doi.org/10.1016/S0024-3205(97)00480-3

[7] M. M. Griffiths, "Immunogenetics of Collagen-Induced Arthritis in Rats," International Reviews of Immunology, Vol. 4, No. 1, 1988, pp. 1-15.

http://dx.doi.org/10.3109/08830188809044766

[8] J. M. Stuart, W. C. Watson and A. H. Kang, "Collagen Autoimmunity and Arthritis," The FASEB Journal, Vol. 2, No. 14,1988 , pp. 2950-2956.

[9] D. E. Trentham, A. S. Townes and A. H. Kang, "Autoimmunity to Type II Collagen an Experimental Model of Arthritis," The Journal of Experimental Medicine, Vol. 146, No. 3, 1977, pp. 857-868. http://dx.doi.org/10.1084/jem.146.3.857

[10] M. A. Cremer, E. F. Rosloniec and A. H. Kang, "The Cartilage Collagens: A Review of Their Structure, Organization, and Role in the Pathogenesis of Experimental Arthritis in Animals and in Human Rheumatic Disease," Journal of Molecular Medicine, Vol. 76, No. 3-4, 1998, pp. 275-288. http://dx.doi.org/10.1007/s001090050217

[11] M. A. Hietala, K. S. Nandakumar, L. Persson, S. Fahlén, R. Holmmahl and M. Pekna, "Complement Activation by Both Classical and Alternative Pathways Is Critical for the Effector Phase of Arthritis," European Journal of Immunology, Vol. 34, No. 4, 2004, pp. 1208-1216. http://dx.doi.org/10.1002/eji.200424895

[12] G. Tu, W. Xu, H. Huang and S. Li, "Progress in the Development of Matrix Metalloproteinase Inhibitors," Current Medicinal Chemistry, Vol. 15, No. 14, 2008, pp. 1388-1395.

http://dx.doi.org/10.2174/092986708784567680

[13] M. Xue, L. March, P. N. Sambrook and C. J. Jackson, "Differential Regulation of Matrix Metalloproteinase 2 and Matrix Metalloproteinase 9 by Activated Protein C: Relevance to Inflammation in Rheumatoid Arthritis," Arthritis \& Rheumatism, Vol. 56, No. 9, 2007, pp. 28642874. http://dx.doi.org/10.1002/art.22844

[14] M. H. Lee and G. Murphy, "What Are the Roles of Metalloproteinases in Cartilage and Bone Damage?" Annals of the Rheumatic Diseases, Vol. 64, No. S4, 2005, pp. iv44-iv47. http://dx.doi.org/10.1136/ard.2005.042465

[15] V. Pham, M. Cadel, C. Gouzy-Darmon, C. Hanquez, M. C. Beinfeld, P. Nicolas, C. Etchebest and T. Foulon, "Aminopeptidase B, a Glucagon-Processing Enzyme: Site Directed Mutagenesis of the $\mathrm{Zn2}+$-Binding Motif and Molecular Modeling," BMC Biochemistry, Vol. 8, 2007, p. 21. http://dx.doi.org/10.1186/1471-2091-8-21

[16] T. D. Penning, M. A. Russell, B. B. Chen, H. Y. Chen, C. D. Liang, M. W. Mahoney, J. W. Malecha, J. M. Miyashiro, S. S. Yu, L. J. Askonas, J. K. Gierse, E. I. Harding, M. K. Highkin, J. F. Kachur, S. H. Kim, D. Villani-Price, E. Y. Pyla, N. S. Ghoreishi-Haack and W. G. Smith, "Synthesis of Potent Leukotriene A(4) Hydrolase Inhibitors. Identification of 3-[methyl[3-[4-(phenylmethyl)phenoxy] propyl]amino] propanoic Acid," Journal of Medicinal Chemistry, Vol. 45, No. 16, 2002, pp. 3482-3490. http://dx.doi.org/10.1021/jm0200916

[17] T. Foulon, S. Cadel and P. Cohen, "Aminopeptidase B (EC 3.4.11.6)," The International Journal of Biochemistry \& Cell Biology, Vol. 31, No. 7, 1999, pp. 747-750. http://dx.doi.org/10.1016/S1357-2725(99)00021-7

[18] M. J. Butler, "Metallopeptidases," In: A. J. Barrett, N. D. Rawlings and J. F. Woessner, Eds., Handbook of Proteolytic Enzymes, Academic Press, London, 1998, pp. 1022 1029.

[19] C. A. Grice, K. L. Tays, B. M. Savall, J. Wei, C. R. Butler, F. U. Axe, S. D. Bembenek, A. M. Fourie, P. J. Dunford, K. Lundeen, F. Coles, X. Xue, J. P. Riley, K. N. Williams, L. Karlsson and J. P. Edwards, "Identification of a Potent, Selective, and Orally Active Leukotriene A4 Hydrolase Inhibitor with Anti-Inflammatory Activity," Journal of Medicinal Chemistry, Vol. 51, No. 14, 2008, pp. 4150-4169. http://dx.doi.org/10.1021/jm701575k

[20] M. T. Mendes and P. F. Silveira, "Quantification of Leukotriene (LT) B4 and LT-A4-Hydrolase (LTA4H) by HPLC and Enzyme Immunoassay (EIA) in an Experimental Model of Arthritis," Abstracts of 14th International Congress on Antiphospholipid Antibodies \& 4th Latin American Congress on Autoimmunity (APLA LACA 2013), Rio de Janeiro, 2013.

http://www2.kenes.com/apla-laca/pages/home.aspx

[21] P. C. Rudberg, F. Tholander, M. M. Thunnissen, B. Samuelsson and J. Z. Haeggstrom, "Leukotriene A4 Hydrolase: Selective Abrogation of Leukotriene B4 Formation by Mutation of Aspartic Acid 375," Proceedings of the National Academy of Sciences of the United States of America, Vol. 99, No. 7, 2002, pp. 4215-4220. http://dx.doi.org/10.1073/pnas.072090099

[22] D. Mantle, G. Falkous and D. Walker, "Quantification of Protease Activities in Synovial Fluid from Rheumatoid and Osteoarthritis Cases: Comparison with Antioxidant and Free Radical Damage Markers," Clinica Chimica Acta, Vol. 284, No. 1, 1999, pp. 45-58. http://dx.doi.org/10.1016/S0009-8981(99)00055-8

[23] F. A. Fitzpatrick, R. Lepley, L. Orning and K. Duffin, "Suicide Inactivation of Leukotriene A4 Hydrolase/Aminopeptidase," Annals of the New York Academy of Sciences, Vol. 744, 1994, pp. 31-38. http://dx.doi.org/10.1111/j.1749-6632.1994.tb52721.x

[24] M. Hui and K. S. Hui, "A Novel Aminopeptidase with Highest Preference for Lysine," Neurochemical Research, Vol. 31, No. 1, 2006, pp. 95-102. http://dx.doi.org/10.1007/s11064-005-9234-9

[25] C. Piesse, S. Cadel, C. Gouzy-Darmona, J. C. Jeanny, V. Carrière, D. Goidin, L. Jonet, D. Gourdji, P. Cohen and T. Foulon, "Expression of Aminopeptidase B in the Developing and Adult Rat Retina," Experimental Eye Research, Vol. 79, No. 5, 2004, pp. 639-648.

http://dx.doi.org/10.1016/j.exer.2004.06.030

[26] K. M. Fukasawa, J. Hirose, T. Hata and Y. Ono, “Aspartic Acid 405 Contributes to the Substrate Specificity of Aminopeptidase B," Biochemistry, Vol. 45, No. 38, 2006, pp. 11425-11431. http://dx.doi.org/10.1021/bi0604577 
[27] S. Cadel, T. Foulon, A. Viron, A. Balogh, S. MidolMonnet, N. Noël and P. Cohen, "Aminopeptidase B from the Rat Testis Is a Bifunctional Enzyme Structurally Related to Leukotriene-A4 Hydrolase," Proceedings of the National Academy of Sciences of the United States of America, Vol. 94, No. 7, 1997, pp. 2963-2968. http://dx.doi.org/10.1073/pnas.94.7.2963

[28] M. T. Mendes, S. Murari-do-Nascimento, I. R. Torrigo, R. F. Alponti, S. C. Yamasaki and P. F. Silveira, "Basic Aminopeptidase Activity Is an Emerging Biomarker in Collagen-Induced Rheumatoid Arthritis," Regulatory Peptides, Vol. 167, No. 2-3, 2011, pp. 215-221. http://dx.doi.org/10.1016/i.regpep.2011.02.012

[29] S. C. Yamasaki, S. Murari-do-Nascimento and P. F. Silveira, "Neutral Aminopeptidase and Dipeptidyl Peptidase IV in the Development of Collagen II-Induced Arthritis," Regulatory Peptides, Vol. 173, No. 1-3, 2012, pp. 47-54. http://dx.doi.org/10.1016/j.regpep.2011.09.004

[30] S. Hwanga and V. Hooka, "Zinc Regulation of Aminopeptidase B Involved in Neuropeptide Production," FEBS Letters, Vol. 582, No. 17, 2008, pp. 2527-2531. http://dx.doi.org/10.1016/i.febslet.2008.06.017

[31] M. Zaitsu, Y. Hamasaki, M. Matsuo, A. Kukita, K. Tsuji, M. Miyazaki, R. Hayasaki, E. Muro, S. Yamamoto, I. Kobayashi, T. Ichimaru, O. Kohashi and S. Miyazaki, "New Induction of Leukotriene A (4) Hydrolase by Interleukin4 and Interleukin-13 in Human Polymorphonuclear Leukocytes," Blood, Vol. 96, No. 2, 2000, pp. 601-609.

[32] J. Gut, D. W. Goldman, G. C. Jamieson and J. R. Trudell, "Conversion of Leukotriene A4 to Leukotriene B4: Catalysis by Human Liver Microsomes under Anaerobic Conditions," Archives of Biochemistry and Biophysics, Vol. 259, No. 2, 1987, pp. 497-509. http://dx.doi.org/10.1016/0003-9861(87)90516-9

[33] G. D. Anderson, K. L. Keys, P. A. De Ciechi and J. L. Masferrer, "Combination Therapies That Inhibit Cyclooxygenase-2 and Leukotriene Synthesis Prevent Disease in Murine Collagen Induced Arthritis," Inflammation Research, Vol. 58, No. 2, 2009, pp. 109-117. http://dx.doi.org/10.1007/s00011-009-8149-3

[34] A. Ryan and C. Godson, "Lipoxins: Regulators of Resolution," Current Opinion in Pharmacology, Vol. 10, No.
2, 2010, pp. 166-172.

http://dx.doi.org/10.1016/j.coph.2010.02.005

[35] J. Z. Haeggstrom, "Structure, Function, and Regulation of Leukotriene A4 Hydrolase," American Journal of Respiratory and Critical Care Medicine, Vol. 161, No. 2, 2000, pp. S25-S31. http://dx.doi.org/10.1164/ajrccm.161.supplement 1.ltta-6

[36] A. W. Ford-Hutchinson, "Leukotriene B4 in Inflammation," Critical Reviews ${ }^{T M}$ in Immunology, Vol. 10, No. 1, 1990, pp. 1-12.

[37] B. Samuelsson, S. E. Dahlén, J. A. Lindgren, C. A. Rouzer and C. N. Serhan, "Leukotrienes and Lipoxins: Structures, Biosynthesis, and Biological Effects," Science, Vol. 237, No. 4819, 1987, pp. 1171-1176. http://dx.doi.org/10.1126/science.2820055

[38] E. Grage-Griebenow, J. Baran, H. Loppnow, M. Los, M. Ernst, H. D. Flad and J. Pryjma, "An Fcy Receptor I (CD64)-Negative Subpopulation of Human Peripheral Blood Monocytes Is Resistant to Killing by Antigen-Activated CD4-Positive Cytotoxic T Cells," European Journal of Immunology, Vol. 27, No. 9, 1997, pp. 2358-2365. http://dx.doi.org/10.1002/eji.1830270934

[39] M. E. Harris, M. Liljestrom and L. Klareskog, "Characteristics of Synovial Fluid Effusion in Collagen-Induced Arthritis (CIA) in the DA Rat; a Comparison of Histology and Antibody Reactivity in an Experimental Chronic Arthritis Model and Rheumatoid Arthritis (RA)," Clinical and Experimental Immunology, Vol. 107, No. 3, 1997, pp. 480-484. http://dx.doi.org/10.1046/j.1365-2249.1997.3311221.x

[40] K. M. Fukasawa, K. Fukasawa, M. Harada, J. Hirose, T. Izumi and T. Shimizu, "Aminopeptidase B Is Structurally Related to Leukotriene-A4 Hydrolase but Is Not a Bifunctional Enzyme with Epoxide Hydrolase Activity," Biochemical Journal, Vol. 339, No. Pt 3, 1999, pp. 497-502.

[41] E. O. De Oliveira, K. Wanga, H. Kong, S. Kim, M. Miessau, R. J. Snelgrove, Y. M. Shim and M. Paige, "Effect of the Leukotriene A4 Hydrolase Aminopeptidase Augmentor 4-Methoxydiphenylmethane in a Pre-Clinical Model of Pulmonary Emphysema," Bioorganic \& Medicinal Chemistry Letters, Vol. 21, No. 22, 2001, pp. 6746-6750. http://dx.doi.org/10.1016/j.bmcl.2011.09.048 